\title{
Area Studies and the Discipline: A Useful Controversy?
}

\section{Citation}

Bates, Robert H. 1997. Area studies and the discipline: A useful controversy? PS: Political Science and Politics 30, no. 2: 166-169.

\section{Published Version}

http://dx.doi.org/10.2307/420485

\section{Permanent link}

http://nrs.harvard.edu/urn-3:HUL.InstRepos:3638435

\section{Terms of Use}

This article was downloaded from Harvard University's DASH repository, and is made available under the terms and conditions applicable to Other Posted Material, as set forth at http:// nrs.harvard.edu/urn-3:HUL.InstRepos:dash.current.terms-of-use\#LAA

\section{Share Your Story}

The Harvard community has made this article openly available.

Please share how this access benefits you. Submit a story.

Accessibility 


\title{
Controversy in the Discipline: Area Studies and Comparative Politics
}

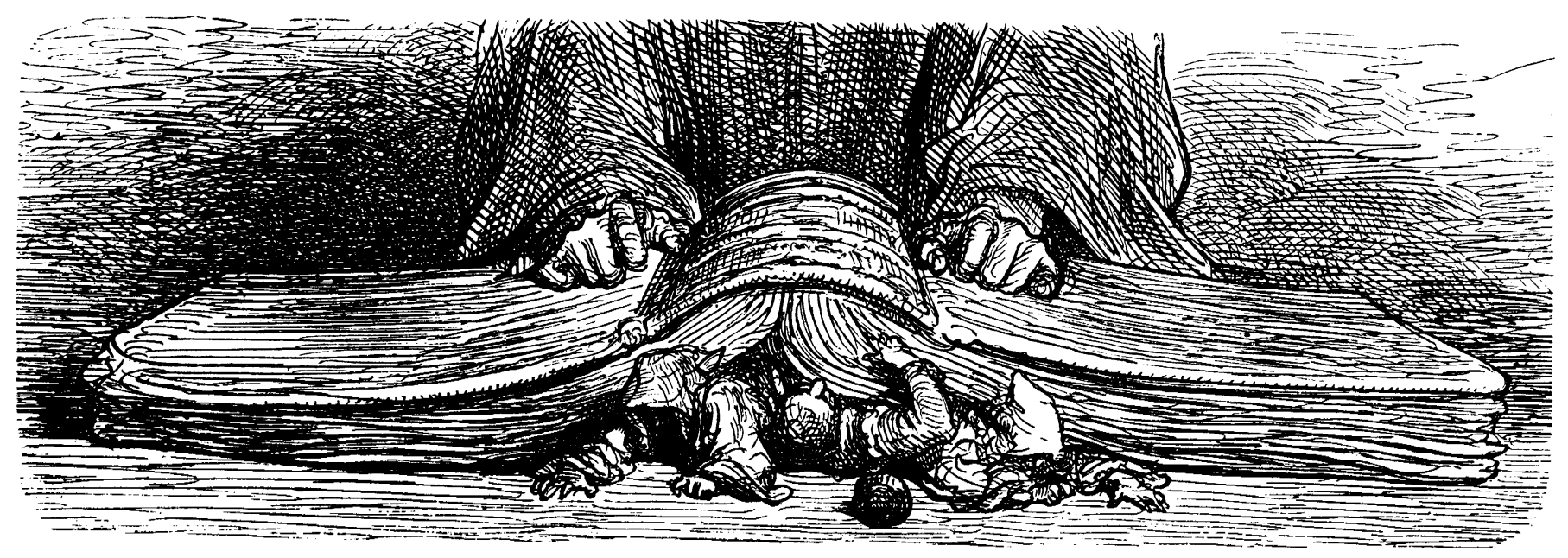

\section{Area Studies and the Discipline: A Useful Controversy?*}

\author{
Robert H. Bates, Harvard University
}

When arguments become polarized, it often signals that divisions are falsely drawn. Such appears to be the case with this controversy. Why must one choose between area studies and the discipline? There are strong reasons for endorsing both. In this essay, I sketch the current debate and explore the ways in local knowledge can and is being incorporated into general analytic frameworks. I conclude by stressing the work that lies ahead. In doing so, it should be stressed, I deal only with political science. The dynamics in other disciplines, I have found, differ greatly from those within our own (Bates et al. 1993).

\section{Caricaturing the Present Divide}

Within political science, area specialists are multidisciplinary by inclination and training. In addition to knowing the politics of a region or nation, they seek also to master its history, literature, and languages. They not only absorb the work of humanists but also that of other social scientists. Area specialists invoke the standard employed by the ethnographer: serious scholarship, they believe, must be based upon field research. The professional audience of area specialists consists of researchers from many disciplines, who have devoted their scholarly life to work on the region or nation.

Those who consider themselves "social scientists" seek to identify lawful regularities, which, by implication, must not be context bound. Rather than seeking a deeper understanding of a particular area, social scientists strive to develop general theories and to identify, and test, hypotheses derived from them. Social scientists will attack with confidence political data extracted from any region of the world. They will approach electoral data from South Africa in the same manner as that from the United States and eagerly address cross-national data sets, thereby manifesting their rejection of the presumption that political regularities are area-bound. Social scientists do not seek to master the literature on a region but rather to master the literature of a discipline.
The professional audience of social scientists consists of other scholars from their discipline who share similar theoretical concerns-and who draw their data from a variety of regions of the world.

Like all caricatures, these depictions distort in order to highlight important elements of reality. The implications of this reality have profoundly unsettled our discipline.

Most immediately, the shift from area studies to "social scientific" approaches has influenced graduate training. Graduate students, whose resources of time and money are necessarily limited, increasingly shift from the study of a region to instruction in theory and methods. When confronted by a choice between a course in African history or one in econometrics, given their constraints, many now choose the latter.

The shift from area specialization to "social science" also alters the balance of power within the academy. Political science departments have long resembled federations, with their faculty in comparative politics dwelling within semi-autono- 
mous, area studies units. Possessing access to resources for seminars, administrative support, fellowships, research and travel independent of the department, the comparative politics faculty has had little reason to defer to the demands of department heads. The move toward a disciplinary-oriented view of comparative politics, and the declining resource base for area studies, has shifted the political center of gravity back to the chairs, who can now apply disciplinary criteria, rather than area knowledge, in evaluating and rewarding professional contributions.

Change in the notions of professional merit also alters the balance of power between generations. Old field hands are giving way to young technicians. It is those in the middle who are the most threatened. Like their elders, they have trained as area specialists; but they are being evaluated by a new set of standards-ones by which they compare unfavorably with younger scholars. The midcareer scholars now scramble to master the new vocabulary and techniques; and departments that once would have readily promoted them too often decide to refrain from doing so, in the expectation of later filling the slots from the best and brightest of the new generation.

The result of these changes is heightened tension within the field, as the controversy resonates with divisions between scholars of different generations, locations within the university, and stages in their careers.

Clearly, the causes of these tensions lie outside the academy: they lie in the rising concerns with government deficits and the end of the cold war. The one has led to reductions in spending for higher education; the other, to a lower priority on area training. For reasons I do not fully understand, rather than cushioning the impact of these changes, foundations have instead exacerbated them by moving in concert with the government. Resources for the study of foreign areas are therefore declining, and we in aca- demics are being required to establish new priorities, as we adjust to tighter constraints.

\section{Reacting to the New Realities}

Many departments were once characterized by a core of technocrats, many of whom specialized in the study of American politics, and a congery of others, many of whom studied foreign political systems. Students of American politics viewed themselves as social scientists; but the political system on which they concentrated, they came to realize, was singularly devoid of variation. Even comparisons across states

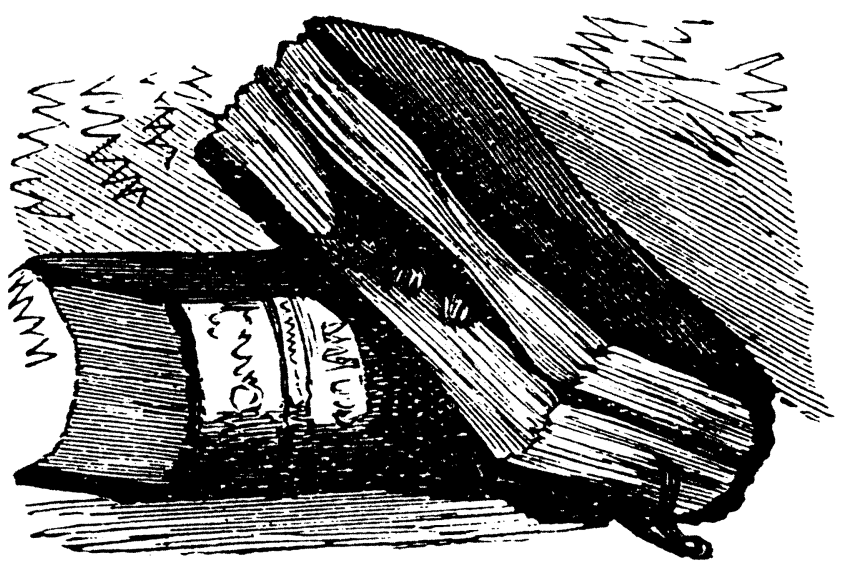

within the greater federation failed to provide insight into differences, say, between presidential and parliamentary systems, much less between polities in market as opposed to centrally planned economies. A vocal minority within American politics had long dismissed students of comparative politics as "mere area specialists;" but the more sophisticated increasingly realized that their hard won, cumulative, scientific knowledge about politics in the United States was itself area-bound. There therefore arose among Americanists a demand for comparative political research, and some of the most theoretically ambitious among them sought to escape the confines imposed by the American political system.

On the one hand, this trend creates allies for comparativists who seek to resist retrenchment; their knowledge of political variation has acquired greater significance. On the other, this trend will promote a transformation in the comparative study of politics; it will force those who have a command of local knowledge to enter into dialogue with those who seek to understand how institutional variation affects political outcomes or who see particular political systems as specific realizations of broader political processes.

Pressures from outside the discipline amplify these changes; they emerge from trends that have affected political systems throughout the world. Following the recession of the 1980 s, authoritarian governments fell, and the collapse of communism in Eastern Europe further contributed to the spread of democracy. This change underscored the broader relevance of the Americanists' research into elections, legislatures and political parties. The spread of market forces and the liberalization of economic systems highlighted the broader significance of research conducted on the advanced industrial democracies as well. The impact of economic conditions upon voting, the politics of central banking, the effect of openness upon partisan cleavages and political institutions: long studied in the Western democracies, these subjects have recently become important, and researchable, in the formerly socialist systems in the North and in the developing nations of the South. As students of comparative politics have addressed them, they have come increasingly to share intellectual orientations, and a sense of necessary skills and training, with their more "social scientific" colleagues in the discipline.

The attention given to King, Keohane, and Verba's Designing Social Inquiry (1994) provides a measure of the impact of these trends. It suggests the urgency with which students of comparative politics feel a need for guidance, as they have sought ways to move from the in depth study of cases, typical of area studies, to sophisticated research 
designs, required for scientific inference.

\section{Deeper Fusion}

The field is thus undergoing significant changes, and the increased stringency of funding strengthens these trends. Less visible, but highly significant, forces run just below the surface and these too will shape the final outcome. Insofar as they do so, they may well define a new synthesis. I refer to a synthesis not only between area studies and the discipline but also between context-specific knowledge and formal theory, as developed in the study of choice.

Area studies emphasizes the importance of cultural distinctions. Cultures are distinguished by their institutions. Game theoretic techniques, established for the study of economic and political organizations, provide a source of formal tools for investigating such institutions. They show how institutions shape individual choices and collective outcomes, and therefore provide a framework for exploring the origins of political difference.

Cultures are also distinguished by their histories and beliefs. The theory of decisions with imperfect information, newly prominent in political science, can be used to explore the manner in which such differences arise and matter. Individuals with similar expectations, it shows, come to diverge in their beliefs if exposed to different data; persons can be shaped by their histories. Even if exposed to the same data, decision theory suggests, persons will revise their beliefs in different ways, if they bring different likelihood functions to bear upon observations. The theory of decisions thus yields insight into the way in which history and world views shape individual choices and therefore collective outcomes. The theory thus provides a framework for exploring cross-cultural differences.

The relationship between "local knowledge" and rational choice theory can be illustrated by Elizabeth
Colson's well-known research into the Plateau Tonga of Zambia (1974). The lives of the Tonga, she reports, resemble the Rousseauian myth, with people residing in peaceful communities, sharing their belongings, and legislating wisely in village assemblies. But, Colson reports, the surface harmony disguises deep fears: of the greed and envy of neighbors, of their wrath, and of their desire and capacity to harm. While the lives of the Plateau Tonga may resemble the accounts of Rousseau, their beliefs, she finds, are bet-

when this is the case formalization inspires new insights as well. Others might be crashingly obvious. But even jejune propositions, if deduced from a theory, are significant; for when they are tested, it is the theory from which they derive that is put at risk. Embedding narrative accounts in theories thus increases the opportunities for testing; it therefore increases our ability to judge the adequacy of an explanation.

By the same token, theory must be complemented by contextual knowledge. Consider the problem faced by an observer who encounters a person who is inflicting damage upon another. If a family head, he may be refusing a request for bride wealth; if a faction leader, he may be withholding patronage; if a mayor, she may be bringing the forces of the law to bear upon a rival political. Such actions inflict harm. But, in interpreting their political importance, the observer will need to know: Do they represent initial defections? Or do they represent punishments for an earlier defection? With-

ter captured in the writings of Hobbes. Colson resolves the paradoxical contrast between beliefs and behavior by arguing that it is the beliefs that support peaceful conduct: people scrupulously choose to act in ways that preserve the peace, she argues, for fear of the violence they would unleash should they impinge upon the interests of others.

Viewed in terms of game theory, Colson's argument represents a claim that behaving courteously constitutes an equilibrium strategy. The strategy is supported in equilibrium by beliefs as to the costs that would be incurred were people to stray from the equilibrium path. It would be easy to use the theory of games to specify the conditions under which the argument follows. More significantly, doing so would suggest additional insights into what must also necessarily be true for the argument to hold. Given that this is so, transforming the narrative into a rational choice account would generate additional testable implications (Ferejohn 1991). Some of these implications might be non-obvious; out knowledge of the history, the investigator cannot determine the significance of these behaviors. The first history suggests that they should be analyzed as a political rupture; the second, that they should be treated as a punishment phase of a game-a phase that may in fact constitute a prelude to reconciliation. In the absence of local knowledge, the actions remain observationally equivalent; nothing in the theory alone suggests their strategic significance and thus their implications for subsequent interactions. Just as in the parable related by Geertz, a "wink" differs from a "twitch," so too does strategic behavior thus require interpretation. To be analyzed correctly, such behavior needs to be addressed by theory that is informed by empirical observation (1973).

To the degree that rational choice theory comes to occupy a central position within the discipline, then, the conflict between area studies and the "social scientific" core of political science will be misplaced. The approach provides explanations for difference; it requires knowledge of 
the difference for the construction and testing of its accounts. It provides a framework which transforms ethnography and narratives into theory-driven claims, amenable to refutation and it requires precisely targeted observations to establish the force of its arguments (Bates et al forthcoming).

It is important to realize that the present debate has been energized by adjacent controversies. It echoes recent ideological struggles. The debate over area studies is often exacerbated by debates over the merits of the market, the state, or the impact of the West, with those who endorse area studies viewing those who use rational choice theory as being pro-market, anti-state, and given to applying historically contingent categories in a universalistic manner. And it resonates with earlier battles over the qualitative and quantitative, between numeracy and literacy, and between the humanities and the sciences. In other cultures, well educated people are expected to excel at both; strength in the one need not imply weakness in the other. But the division remains powerful within our own culture, particularly among academics, where it limits and impedes. It reinforces the foundations for the present debate between area studies and the discipline.

Not being hard-wired, the division between "the scientific" and "the humanistic" can be transcended. The issue is not whether to use the left side of the brain rather than the right. It is, rather, how to employ both. The combination of local knowledge and general modes of reasoning, of area studies and formal theory, represents a highly promising margin of our field. The blend will help to account for the power of forces that we know shape human behavior, in ways that we have hitherto been able to describe but not to explain. It is time to insist upon the pursuit of both rather than upon the necessity of choosing sides.

\section{Conclusion}

To pursue this agenda, departments will have to accommodate the special needs of graduate training in comparative politics. For not only will our students need to possess area skills, such as languages; they will also need training in the skills long expected of students in the American subfield: formal theory, statistics, and the mathematics to do both. Others will need to train in economics as well. Just when university administrators are seeking to reduce the length of time necessary to secure a degree, this subfield will need to accommodate longer residencies. Administrators and department heads will have to adjust their programs accordingly.

Perhaps as a complement, departments will also have to re-think their approach to evaluating junior personnel. Unless fortunate enough to be a native speaker of a foreign language or to possess an unusually strong mathematical background, most junior faculty will not be able to consolidate both area and analytic skills prior to facing the tenure hurdle, much less to produce research demonstrating a confident command of both. In making promotion decisions, then, rather than focusing purely on product, attention will have to be placed on investment: If initially in command of research methodologies, have the young scholars used their initial years to learn the history of their area or its languages? If emerging from an area-based program, have they taken themselves to the classrooms in the statistics, economics, or mathematics departments? The deliberations regarding tenure in comparative politics may therefore have to differ from those in other portions of the discipline. Questions such as these will have to be addressed and the answers given greater weight than in other subfields.

In earlier decades, the Social Science Research Council gave midcareer grants, enabling professors to return to the classroom. These grants virtually made possible the creation of "hybrid" fields, such as economic history. Historians trained as economists, and economists as historians. Clearly, the creation of such an awards program would represent a timely response to the present crisis.

How will we know when reconciliation has been achieved? One test will be the capacity of someone who has invested heavily in the knowledge of an area to respond to a dean, provost, or departmental chair who inquires: "What has the study of your area contributed to the broader discipline?" Each of us who specializes in the study of an area should be able to respond to this question. We will, I am afraid, increasingly have to do so.

\section{Note}

\begin{abstract}
* This article draws heavily on Robert $\mathrm{H}$. Bates, "Area Studies and Political Science: Rupture and Possible Synthesis," Africa Today, Volume 44, No. 2 (1997), special issue on "The Future of Regional Studies." I wish also to thank Timothy Cotton and Peter Hall, and the junior fellows of Harvard Academy, especially Daniel Posner, for their tough criticisms. I have failed to incorporate many of their suggestions, and therefore must assume complete responsibility of the defects that remain.
\end{abstract}

\section{References}

Bates, Robert H., Jean O'Barr, and V. S. Mudimbe, 1993. Africa and the Disciplines. Chicago: University of Chicago Press.

Bates, Robert H., Avner Greif, Margaret Levi, Jean-Laurent Rosenthal, and Barry Weingast. Forthcoming. Analytic Narratives.

Colson, Elizabeth. 1974. Tradition and Contract. Chicago: Aldine.

Ferejohn, John. 1991. "Rationality and Interpretation," in The Economic Approach to Politics, ed. Kristen Renwick Monroe. New York: Harper Collins.

Geertz, Clifford. 1973. Interpretation of Cultures. New York: Basic Books.

King, Gary, Robert Keohane, and Sydney Verba, 1994. Designing Social Inquiry. Princeton: Princeton University Press.

\footnotetext{
About the Author

Robert Bates is Eaton Professor of the Science of Government at Harvard University. Among his recent books is Africa and the Disciplines (Chicago, 1993), with Jean O'Barr and V. Y. Mudimbe.
} 